\title{
A BAYESIAN RE-ASSESSMENT OF THE EARLIEST RADIOCARBON DATES FROM TIWANAKU, BOLIVIA
}

\author{
Erik J Marsh \\ Department of Anthropology, University of California, Santa Barbara, California 93106, USA. \\ Email: emarsh@umail.ucsb.edu.
}

\begin{abstract}
The development of sociopolitical complexity at Tiwanaku around AD 500 was one of the major episodes of social change in the history of the Lake Titicaca Basin. It was the result of poorly understood processes that took place at a series of ceremonial centers in the preceding centuries. The history of Tiwanaku during this time is especially unclear, because the only radiocarbon dates are from excavations whose details were never completely published. Despite this, there is consensus that Tiwanaku was founded around $300 \mathrm{BC}$. A re-evaluation of the archaeological context of each of these dates shows many of them to be unreliable. Two Bayesian models from independent excavations agree that Tiwanaku was in fact founded centuries later, most likely around AD $110(50-170,1 \sigma)$. This has important implications for widely used monolith and ceramic sequences, as well as understanding the rise of Tiwanaku and other archaic states.
\end{abstract}

\section{INTRODUCTION}

The development of sociopolitical complexity at Tiwanaku around AD 500 was one of the major episodes in the culture history of the Lake Titicaca Basin (Figure 1). Rapid social and historical processes in the first few centuries AD foreshadowed the emergence of one of the world's few primary states. Compared to other global examples of primary states, this is a poorly known but strongly relevant case for understanding the emergence of complexity more generally (Stanish 2003:164-5; Janusek 2004a:140-51).

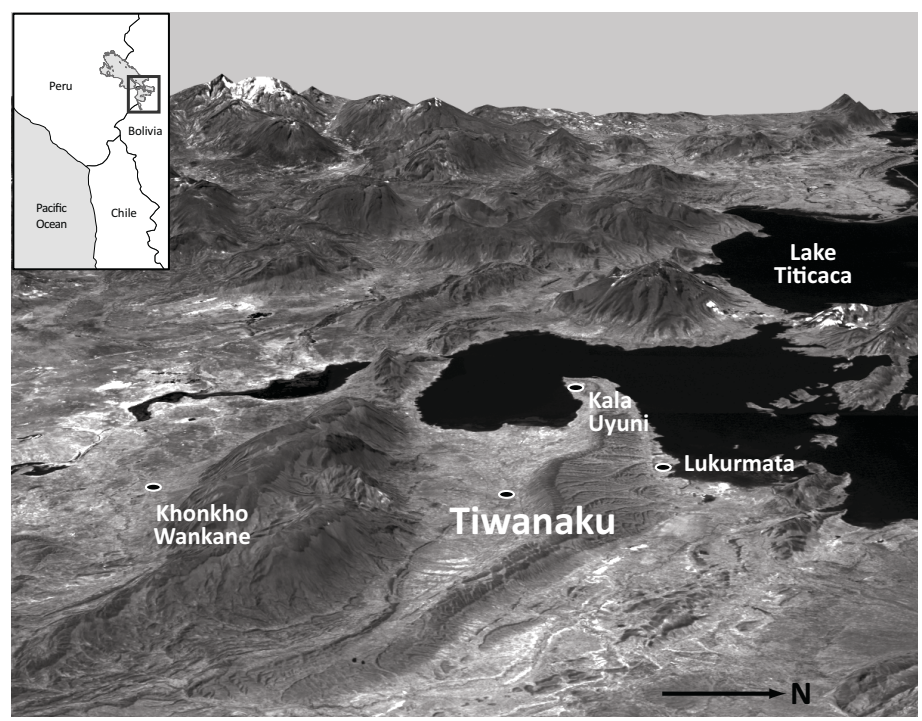

Figure 1 Perspective map of the southern Titicaca Basin, as seen from the southeast, indicating selected Late Formative ceremonial centers. Based on a composite map by Arik Ohnstad, using Landsat and SRTM topographic data.

The process of state emergence undoubtedly involved groups at many different sites, but Tiwanaku saw the most dramatic and enduring changes. The early history of Tiwanaku itself is an especially vague point in the culture history, including when it was founded. Until very recently, there were only 2 sets of early ${ }^{14} \mathrm{C}$ dates from Tiwanaku, from the lowest levels of Kidder's pits and the Kala- 
sasaya temple. In neither case were the contexts or associated artifacts adequately described, resulting in a vague chronology. In spite of this serious limitation, the dates have been used to anchor widely used stylistic sequences of Kalasasaya ceramics and Yaya-mama monoliths (Chávez and Mohr Chávez 1975:66; Janusek 2003:46-7, 51-2). The dates are also the basis for Ponce Sanginés' (1981) prominent narrative of the evolution of the Tiwanaku state. The early history of this future state capital is often treated as diagnostic of changes at other nearby sites, so adjustments to the chronology of Tiwanaku impact the history of the entire southern Titicaca Basin.

This paper reconsiders the earliest radiocarbon dates from Tiwanaku, in the spirit of Kra's (1986: 765) call to "re-evaluate" potential problems with dates and their contexts, especially those processed during the early years of ${ }^{14} \mathrm{C}$ dating. I attempt to correct the long-running precedent of accepting these poorly described dates uncritically. The Bayesian models are simple and based on few dates, but seek to make the most of the limited available information. The models significantly adjust the medians and reduce the wide sigma ranges, a valuable tool for increasing chronological resolution in areas and periods with few dates. This represents the first known use of Bayesian models in the Titicaca Basin, which have unexplored potential to generate high-resolution chronologies at other sites as well.

First, I describe the current picture of Tiwanaku's early history, based on ${ }^{14} \mathrm{C}$ dates and ceramics from excavations during the 1930s and 1950s directed by Bennett, Kidder, and Cordero Miranda. Next, I consider the potential reliability of each date, based on stratigraphic relationships and the descriptions of associated contexts. I model the reliable dates using Bayesian models, which suggest that Tiwanaku was founded in the 1st or 2nd century AD. This has important implications for ceramic and monolith sequences, as well as for the social history of Tiwanaku itself. It suggests very rapid processes of social change, in contrast to existing models of slow, gradual growth. A reassessment of these dates is relevant for archaeologists working in the region, as well as those interested in the pace of archaic state formation.

\section{Ponce Sanginés' Narrative}

Ponce Sanginés (1981) proposed one of the most prominent narratives of Tiwanaku's origins, which uncritically aligned sparse data with Childe's (1950:13-6) evolutionary expectations. It described Tiwanaku as a self-sufficient village, which later created agricultural surpluses, leading to urban development in the first centuries AD, and finally to the rise of the state (Ponce Sanginés 1981:758; see Burkholder 1997:8-9, 45-6; Janusek 2004b:65).

The narrative's chronology used $30{ }^{14} \mathrm{C}$ dates, arranged into 5 cultural phases (Ponce Sanginés 1981: Table 1; Janusek 2003: Table 3.2). Each phase was dated based on the order of the ${ }^{14} \mathrm{C}$ dates, disregarding stratigraphic relationships and associated ceramics (Albarracín-Jordan 2007:34-5). The narrative is more akin to an "interpretative argument" than a stratigraphic sequence, though is often treated as such (Isbell et al. 2002:143; see Stanish 2003:88). Tiwanaku I, II, and III are the earliest phases, though the dates used to define them are statistically indistinct (Mathews 1992:65, 103, Figures 24, 44, and 45; Augustyniak 2004:32-3).

Ponce Sanginés suggested that Tiwanaku was founded around $1580 \mathrm{BC}$, the median of the earliest date (GaK-194). The first phase, Tiwanaku I, was dated to 237 BC (Ponce Sanginés 1993:65). This is an arithmetic average of the means of the 9 earliest dates, a poor means of assessing the absolute date of the associated archaeological material. Stylistic comparisons of Tiwanaku's earliest ceramics and monoliths suggested that the site could not be much older than a few centuries BC (Rowe 1963: 8; Chávez and Mohr Chávez 1975:66). The earliest date was excluded as an outlier decades ago; the 
current consensus is that Tiwanaku was founded no earlier than $300 \mathrm{BC}$, slightly before the beginning of the Late Formative period (Kigoshi and Endo 1963:116; Browman 1980:114; Bermann 1990:86, 1994:66; Mathews 1992:66-7; Janusek 2003:47; Stanish 2003:117). Late Formative ceramics are the earliest diagnostic ceramics at Tiwanaku (Marsh, forthcoming).

\section{Late Formative Ceramic Chronology}

The current ceramic chronology suggests that the Late Formative period dates to $200 \mathrm{BC}-\mathrm{AD} 500$ (Janusek 2003:37). The dating of this period is based on all but one of the dates Ponce Sanginés (1981) used, which may provide a "general idea of time span involved," but are weak chronological referents (Janusek 2003:47). Partially for this reason, the Late Formative remains "the most problematic" in the entire prehispanic sequence (Bandy 2001:174).

Janusek proposes 3 phases within the Late Formative, which are essentially updates of Tiwanaku I, II, and III (2003:37-40):

- Late Formative 1A (200 BC-AD 250). Kalasasaya red-rimmed vessels are common. Kalasasaya zonally incised vessels are present, but rare.

- Late Formative 1B (AD 250-300). No decorated ceramics.

- Late Formative 2 (AD 300-500). Kalasasaya red-rimmed vessels are present, but much less common. Qeya style vessels are present, but rare.

The proposed span of Late Formative 1A is based on all but 1 date from strata 6 and 7 of the Kalasasaya, which have a "combined $1 \sigma$ range spanning $1300 \mathrm{yr}$, from $840 \mathrm{BC}$ to $\mathrm{AD} 400$. But there is a tighter central range from about $200 \mathrm{BC}$ to AD 250" (Janusek 2003:47). The span for Late Formative $1 \mathrm{~B}$ is based on 3 dates from stratum 5 of the Kalasasaya, whose overlapping $1 \sigma$ ranges mostly span AD 140 to 400, accommodated to AD 250-300. Late Formative 2's span is based on 5 of Kidder's dates, which have an "80 percent overlap of $1 \sigma$ ranges spanning AD 210-600" (Janusek 2003: 51). Janusek uses almost the same sets of dates as Ponce Sanginés to define Tiwanaku I, II, and III, applying them to Late Formative 1A, 1B, and 2, respectively. Taking these uncontextualized dates at face value, their wide, overlapping $1 \sigma$ ranges do not support the proposed temporal spans, which are in fact statistically indistinguishable (Mathews 1992:65; Augustyniak 2004:32).

The ceramic chronology is based on dates calibrated with Stuiver and Pearson's (1993) curve (Janusek 2003:35), though most research that relies on this ceramic sequence uses different calibration curves. Even though this is the standard ceramic sequence in the region, the basis for its absolute chronology echoes the fallacies behind the dating of Ponce Sanginés' narrative.

\section{METHODS}

This article calibrates dates with IntCa109 (Reimer et al. 2009), and models them with Bayesian statistics implemented in OxCal v 4.1 (Bronk Ramsey 2008, 2009). I report medians and $1 \sigma$ ranges in the text; $2 \sigma$ ranges are reported in the tables. Calibrated and modeled dates are rounded by $10 \mathrm{yr}$.

Tiwanaku is located in the Southern Hemisphere, where recent research suggests that a hemispherespecific calibration curve may apply, SHCal (McCormac et al. 2004). However, this article uses the international curve IntCal, for 4 reasons. First, IntCal may be appropriate for the Titicaca Basin, given its proximity to the Intertropical Convergence Zone (ITCZ) and the austral summer growing season (Finucane et al. 2007:581). Second, SHCal is based on tree-ring data that span AD 9501950 , later than the period in question. Third, the roughly 50-yr difference between the IntCal and SHCal curves is minor in absolute terms, and almost negligible in relative terms (McCormac et al. 
2004:1088; Hogg et al. 2009:1176). Fourth, there is no consensus among Andean archaeologists to switch to SHCal, or to use a fixed offset (Unkel et al. 2007:556). For the time being, using the IntCal curve enables more direct comparisons to other dates in the region, which are most commonly calibrated with this curve. This may soon change, as statistical analyses support the validity of SHCal for dates older than AD 950 (Hogg et al. 2009:1165).

At Tiwanaku, culture histories and ceramic chronologies attempt to accommodate most if not all of the 30 dates from Kidder's pits and the Kalasasaya, even though a number of them are questionable; only 1 includes clearly described cultural material. These dates were originally presented decades ago, with very basic contextual information (Ralph 1959:55-6; Kigoshi et al. 1962:91; Wendt et al. 1962:106-7; Kigoshi and Endo 1963:116; Stuckenrath 1963:95; Oeschger and Riesen 1965:7; Ponce Sanginés 1970: Table 5). Many of them have been compiled and calibrated in more recent publications (Ponce Sanginés 1981: Tables 1-14; Couture 2002: Appendix A.2; Janusek 2003: Table 3.2). Here, I do not address the 9 dates that fall after the Late Formative (Table 1).

Table 1 Dates that fall after the Late Formative.

\begin{tabular}{llllll}
\hline & Pit & Stratum or level & Lab code & ${ }^{14} \mathrm{C}$ age $(\mathrm{BP})$ & Depth $(\mathrm{m})$ \\
\hline Kidder's pits & $\mathrm{A}$ & $8-10$ & $\mathrm{P}-120 \mathrm{~A}$ & $1226 \pm 100$ & $1.75-2.50$ \\
& $\mathrm{~A}$ & $6-7$ & $\mathrm{P}-121,121 \mathrm{~A}, 122$ & $1423 \pm 175$ & $1.25-1.75$ \\
& $\mathrm{~A}$ & 9 & $\mathrm{P}-120$ & $1702 \pm 103$ & $2.0-2.25$ \\
\cline { 2 - 6 } & $\mathrm{B}$ & 1 & $\mathrm{P}-146$ & $949 \pm 88$ & $<0.75$ \\
\hline Kalasasaya & & & Hv-17 & $240 \pm 80$ & 0.50 \\
& G-15 & 3 & P-531 & $295 \pm 192$ & $0.85-1.10$ \\
& E-14 & 3 & GaK-51 & $630 \pm 110$ & \\
& F-8 & & P-533 & $778 \pm 133$ & $1.10-1.35$ \\
\hline Kheri-Kala & 10 & 2 & M-1049 & $780 \pm 150$ & \\
\hline
\end{tabular}

The few published details can be used to evaluate whether each date was from a reliable archaeological context. Ten dates are excluded, based on the following criteria (Table 2):

- The original laboratory report considered them questionable.

- Different runs of a single sample produced divergent results.

- They are out of stratigraphic sequence, i.e. deeper levels should be older.

- They clearly disagree with other dates from the same level.

- They clearly disagree with the period suggested by diagnostic ceramics.

- They are not associated with any cultural materials.

Eleven reliable Late Formative dates are incorporated into 2 Bayesian models, in order to refine the timespans associated with Tiwanaku's founding and earliest occupations. The modeled dates suggest that Tiwanaku was probably founded in the 1st or 2nd century AD.

\section{DESCRIPTION OF EXCAVATIONS}

\section{Bennett's and Kidder's Pits}

For many years, the only available data in the region on the Late Formative period came from Tiwanaku itself, where Late Formative contexts are often heavily disturbed and usually located below meters of trash and construction fill. Bennett's (1934) ceramic chronology placed Late Formative ceramics in the "Early Tiahuanaco" period, defined by 2 types of decorated sherds, though most of the assemblage comprised undecorated sherds (Bennett 1934:399; Janusek 2003:32). Exca- 
Table 2 Unreliable dates.

\begin{tabular}{|c|c|c|c|c|c|}
\hline Pit & $\begin{array}{l}\text { Stratum } \\
\text { or level }\end{array}$ & $\begin{array}{l}\text { Lab } \\
\text { code }\end{array}$ & $\begin{array}{l}{ }^{14} \mathrm{C} \text { age } \\
(\mathrm{BP})\end{array}$ & $\begin{array}{l}\text { Depth } \\
(\mathrm{m})\end{array}$ & Reasons date is unreliable \\
\hline Kidder's pit B & $6-7$ & P-147 & $1576 \pm 104$ & $1.80-2.30$ & $\begin{array}{l}\text { Untreated samples of wet, slightly charred } \\
\text { bones; contaminated by groundwater }\end{array}$ \\
\hline Kidder's pit B & 8 & P-119 & $1460 \pm 200$ & $2.30-2.85$ & $\begin{array}{l}\text { Untreated samples of slightly charred } \\
\text { bone; contaminated by groundwater }\end{array}$ \\
\hline Kalasasaya K-16 & 6 & GaK-194 & $3530 \pm 120$ & 3.28 & Clear statistical outlier \\
\hline Kalasasaya F-14 & 6 & B-488 & $2400 \pm 200$ & 2.55 & \multirow{3}{*}{$\begin{array}{l}\text { No associated cultural materials; older } \\
\text { than deeper dates; likely construction fill }\end{array}$} \\
\hline Kalasasaya E-14 & 6 & B-489 & $2530 \pm 200$ & 2.70 & \\
\hline Kalasasaya E-14 & 6 & GaK-52 & $2190 \pm 130$ & 2.70 & \\
\hline Kalasasaya F-15 & 4 & GaK-53 & $2410 \pm 140$ & - & $\begin{array}{l}\text { Older than diagnostic ceramics at } 2 \sigma \text {; } \\
\text { older than deeper dates; deep stratum of } \\
\text { mixed construction fill }\end{array}$ \\
\hline Kalasasaya K-12 & 4 & M-1047 & $1950 \pm 150$ & - & \multirow{3}{*}{$\begin{array}{l}\text { Older than diagnostic ceramics at } 1 \sigma \text {; } \\
\text { older than deeper dates; deep stratum of } \\
\text { mixed construction fill }\end{array}$} \\
\hline Kalasasaya K-11 & 4 & Hv-18 & $1630 \pm 130$ & 1.75 & \\
\hline Kalasasaya F-15 & 4 & $\mathrm{~B}-490$ & $2100 \pm 200$ & - & \\
\hline
\end{tabular}

vating in 50-cm arbitrary levels, the 1932 expedition found Late Formative ceramics in pit V, levels 6-9, and pit VIII, levels 4-6 (1934:447-8). In 1955, Kidder (1967:138) excavated 2 pits "as close as possible" to Bennett's pits (see Janusek 2003:33; Albarracín-Jordan 2007:32). Kidder's pit A was $4.5 \mathrm{~m}$ north of Bennett's pit $\mathrm{V}$ and Kidder's pit B was immediately north of Bennett's pit VIII (Ponce Sanginés 1995:174-5). Kidder excavated in 25 -cm arbitrary levels and ran $9{ }^{14} \mathrm{C}$ dates (Ralph 1959: 55 ), which can be used to estimate dates for Bennett's ceramics.

\section{Bennett's Pit VIII and Kidder's Pit B}

Given the proximity of Bennett's VIII and Kidder's B pits, there may be a rough stratigraphic association, though the precise correlation of levels is not clear (Ralph 1959:55). Bennett found Late Formative ceramics in levels 4-6, about 1.0-2.5 m below the surface, at the same depths as Kidder's levels 5-10. Kidder's levels 6-8 included Late Formative ceramics, such as incised sherds with geometric designs, and a polychrome incised sherd from level 8, probably in the Kalasasaya zonally incised style (Ralph 1959:55; Mohr Chávez 1987:2). Red-rimmed Kalasasaya bowls were present in all 3 of Bennett's levels, and in Kidder's collections (Bennett 1934:309, 414, 424, Table 3; Mohr Chávez 1987:2).

Kidder ran 3 dates from this pit, 2 of which were associated with Late Formative ceramics (Ralph 1959:55-6). Comparisons with Bennett's excavations suggest that levels were in chronological order; there is no indication of intrusive pits or inverted stratigraphy. However, both dates seem unreliable (Table 2). They are a few centuries younger than expected, based on comparisons to dates, levels, and ceramics in pit A (Ralph 1959:55-6). This is a suggestive but not compelling reason to consider them unreliable, as the wide sigma ranges do cover the expected temporal span. However, both were of charred bone, and may have been contaminated by groundwater at the bottom of the pit. This may have resulted in dates that are "erroneously young ... by as much as $500 \mathrm{yr}$ " (Ralph 1959:55-6). These samples were processed in the 1950s and were probably not pretreated, which is necessary for a reliable result.

\section{Bennett's Pit V and Kidder's Pit A}

Bennett's pit V and Kidder's pit A were "directly adjacent," and there seems to be a rough stratigraphic association (Ralph 1959:54). The upper $2.5 \mathrm{~m}$ of both pits included Tiwanaku period ceramics, as well as construction events and intrusive pits (Figure 2a; Bennett 1934: Figures 5-9). Below 
this, there is a clear stratigraphic break, marking the division between Tiwanaku period and Late Formative ceramics (Ralph 1959:55). The stratigraphic division included water-worn stones and semi-barren clay, possibly construction materials. Bennett recovered unmixed Late Formative ceramics in levels 6-9, and sterile soil at a depth of $4.6 \mathrm{~m}$. The deepest level represents the initial occupation of Tiwanaku, which included sherds from Kalasasaya zonally incised and red-rimmed vessels (Bennett 1934:447-8, 453). These levels probably included "dwelling refuse" of Late Formative residents (Bennett 1934:383). Domestic structures were not encountered in Bennett's small pits, but were in Ponce Sanginés’ more horizontal excavations (see below).

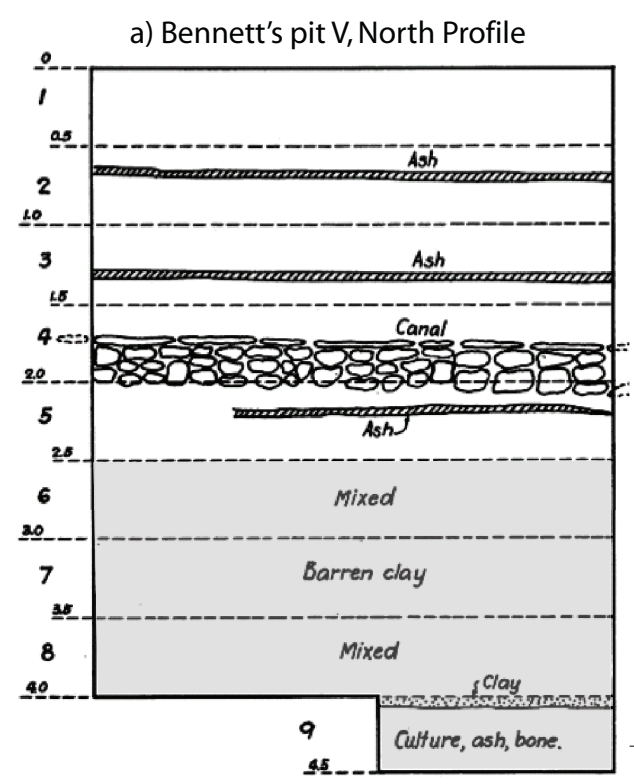

b) Extrapolated dates for each level

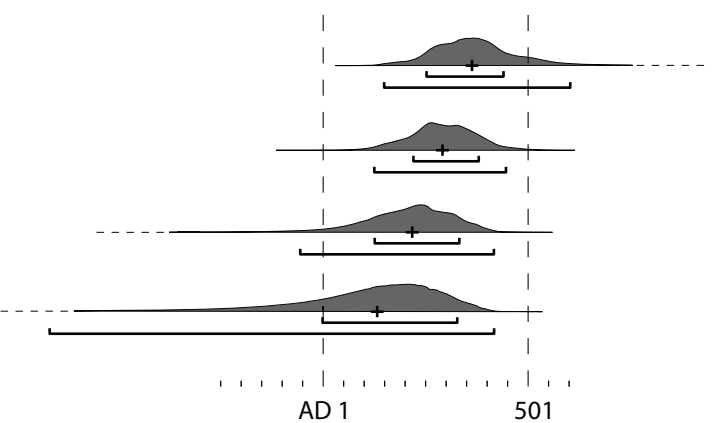

Figure 2 Modeled and extrapolated dates for Bennett's pit V and Kidder's pit A: (a) north profile of Bennett's pit V, indicating levels and depths. Shaded levels include Late Formative ceramics, modified from Bennett (1934: Figure 9); (b) extrapolated dates of levels in Bennett's pit. Below each curve, the cross indicates the median and the bars indicate $1 \sigma$ and $2 \sigma$ ranges.

Kidder ran 6 dates from pit A. Three of them fall after the Late Formative and are associated with Tiwanaku period ceramics (Table 1). Two of these dates may be unreliable, for the same reasons as the unreliable bone samples in pit B.

Kidder's pit A included 3 reliable ${ }^{14} \mathrm{C}$ dates from levels deeper than $2.5 \mathrm{~m}$. None are from charred bone samples, and the dates agree with their stratigraphic order and associated ceramics. The Bayesian model is based on these 3 dates, and provides estimates of absolute ages for Bennett's ceramics (Appendix, Figure 2b, Table 3; Bennett 1934:477, Tables 2, 3, and 5). It treats each of Bennett's four 0.5-m levels as a phase, 3 of which include ${ }^{14} \mathrm{C}$ dates from Kidder's pit A (Bennett 1934:378-85, Figures 6-9; Ralph 1959:55). The model assumes that levels were deposited in order. There seems to have been a broadly uniform rate of deposition, though the model does not make this assumption, resulting in a more conservative model with wider error ranges (Bronk Ramsey 2008:48). The extrapolated ages estimate the age of the ceramics in each level, which may be useful for future research on Bennett's and Kidder's collections. 
The clearest temporal indicators are the marked stratigraphic boundaries. The boundary between sterile soil and the deepest cultural layer suggests the site was founded around AD 90 (80 BC-AD 340). Late Formative ceramics continue through level 6, after which Tiwanaku period ceramics appear, a boundary modeled to AD 400 (250-490). In sum, correlating Bennett's excavation with Kidder's dates suggests that Tiwanaku was first occupied no earlier than the 1st century BC, as suggested by Rowe (1963:8), and more likely in the 1st or 2nd century AD. Ceramics from both pits suggest that the site's founders used Kalasasaya red-rimmed and zonally incised vessels.

\section{The Kalasasaya}

In 1957 and 1958, Gregorio Cordero Miranda directed excavations in the Kalasasaya temple, one of the principal monuments at Tiwanaku (Ponce Sanginés 1995:226-8). Excavations of 73 units covered $1825 \mathrm{~m}^{2}$, part of a large project whose goals included investigating the site's earliest occupation (Ponce Sanginés 1993:51). ${ }^{1}$ Late Formative occupations were revealed in a number of units, indicated in the 2 published profiles (Figure 3; Ponce Sanginés 1993:50-4; Couture 2002:95-101; Janusek 2003:37-8). Sterile soil was reached in stratum 8, immediately below the deepest stratum with cultural materials (stratum 7). This stratum is an occupational layer with carbon, ash, ceramics, burials, and stone foundations. Above this lies a "sterile, silty layer" (stratum 6), followed by a second occupational stratum (5) with carbon lenses and undecorated ceramics (Ponce Sanginés 1993:53, translation by author). Next, residential occupation of the area ended and the Kalasasaya temple was built. Overlaying stratum 5 , stratum 4 comprises about $2 \mathrm{~m}$ of mixed construction fill.

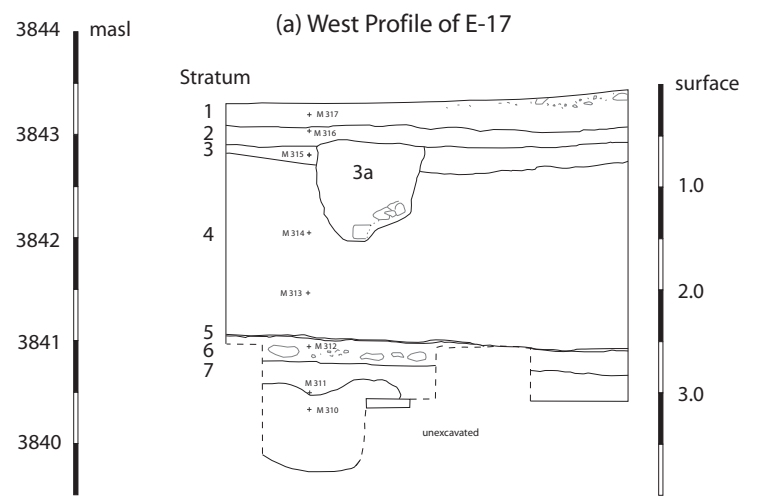

(b) West Profile of D-16

Figure 3 Profiles from the Kalasasaya excavations, redrawn from Ponce Sanginés (1993: Figure 13.2, 1995: Figure 14.2). The crosses labeled with "M" may indicate the locations of samples (muestras), though this is not clear.

There is some basic information on these dates' stratigraphic relationships and material associations. Dates from strata 5 and 7 are considered reliable, as they are associated with organic matrices, cultural material, and structure foundations. On the other hand, strata 4 and 6 are probably construction fills, and the associated dates are not reliable.

Stratum 6 is a layer of "neutral grey clay" (Kigoshi et al. 1962:91); none of the 4 dates from this stratum seem to be reliable. Parts of 1 sample were sent to 2 different laboratories, samples B-489 and GaK-52 (Table 2; Kigoshi et al. 1962:91; Oeschger and Riesen 1965:7; Ponce Sanginés 1970:

${ }^{1}$ This excavation and associated ceramics were first presented at the 34th International Conference of Americanists in Lima, 2-9 August 1970. They were subsequently published in different venues with very minor modifications (Ponce Sanginés 1971, 1976, 1993). I refer to the most recent publication, which includes a slightly expanded description of the stratigraphy and additional figures. 

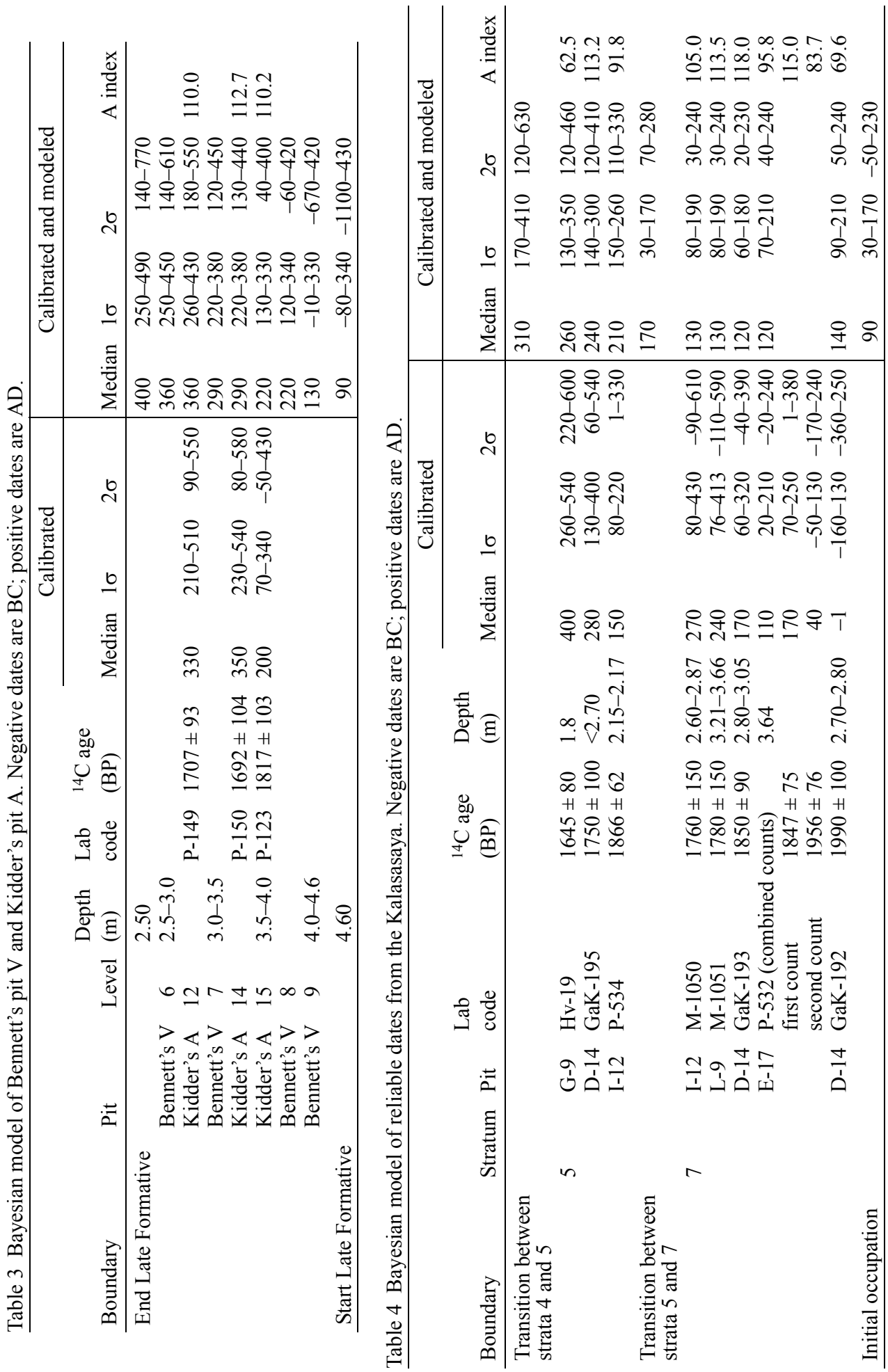
Table 5). The divergent results are unexpected, but the large error ranges do not statistically disagree. Clearer reasons to question this stratum's dates begin with GaK-194, a statistical outlier. Second, the dates are out of stratigraphic order, as they are much older than dates from the deeper stratum 7. Third, and most importantly, there are no cultural materials associated with stratum 6 , reported as sterile. Rather than an occupation layer, it was probably construction fill, as suggested by the stones indicated in the profile drawing (Figure 3). Clay from similar depths was reported in Bennett's pit. The dated samples may have been from clays used in construction fills, a common construction practice at the time. Finally, there are no other accepted Late Formative dates from Tiwanaku or any other site in the region that are as old. For these reasons, all 4 dates from stratum 6 are unreliable.

The dates from stratum 4 are unreliable for similar reasons. Two samples from the same excavation pit and the same stratum were sent to different laboratories, GaK-53 and B-490 (Table 2). While very different, these dates' error ranges allow for the possibility that they are correct. First, 3 of the 4 are out of stratigraphic order, much older than dates from the deeper strata 5 and 7 . Second, if this level was construction fill, it was probably placed within a relatively short span. Unexpectedly, the dates have $1 \sigma$ spans covering nearly 1000 yr. Third, the fill includes Qeya ceramics, a style used after AD 300, much later than 3 of the 4 dates (Table 2; Janusek 2003:38). This strata is interpreted as imported construction fill (Ponce Sanginés 1993:53). The stratum is up to $2 \mathrm{~m}$ deep, but there is no indication of which part of the fill the dated samples derive. One date does appear to correspond to its stratigraphic position and associated ceramics (Hv-18). However, given the mixed nature of the deposit, none of the dates from stratum 4 are considered reliable.

On the other hand, all 8 dates from strata 5 and 7 are associated with cultural material and seem to be reliable. Stratum 5 includes $3{ }^{14} \mathrm{C}$ samples from a thin stratum with carbon, ash, and ceramics with mica inclusions (Ponce Sanginés 1993:53; Janusek 2003:38, Table 3.2). All 3 dates' medians fall within a few centuries of each other. Stratum 7's dates are also within this same range, and are generally earlier than stratum 5's dates, as would be expected based on their stratigraphic position.

One important exception is date P-532, from a cache of 24 complete vessels in pit E-17, which includes 11 rare Kalasasaya zonally incised vessels. This is the only dated context for which there are descriptions of associated materials (Ponce Sanginés 1993:55). This context's originally published date (Stuckenrath 1963:95) seems to be a few centuries too young, based on its stratigraphic position and style of the associated ceramics (Rowe 1963:8; Oeschger and Riesen 1965:7; Ponce Sanginés 1970:61, Figures 32-34; Chávez and Mohr Chávez 1975:66; Stanish 2003:138). This possibility is also supported by comparisons to ceramics from other sites in the southern Titicaca Basin, where all Kalasasaya zonally incised sherds date to the earlier part of the Late Formative (Marsh 2012:402).

A revised ${ }^{14} \mathrm{C}$ age for sample P-532 was included in a 1962 letter to Ponce Sanginés from Robert Stuckenrath, the director of the Pennsylvania laboratory that processed the sample (Steadman 1995: 147). The letter indicates 2 counts for the sample, $1956 \pm 76$ and $1847 \pm 75$ BP (Ponce Sanginés 1970: Table 5). The model presented here uses these 2 counts, combined and calibrated to AD 110 (20-210), a date that meets stylistic and stratigraphic temporal expectations.

\section{Bayesian Model of the Kalasasaya Occupation}

The Bayesian model for the Kalasasaya occupation groups the dates from strata 5 and 7 as 2 phases, and assumes the former postdates the latter, given their clear stratigraphic superposition (Appendix, Figure 4, Table 4; Janusek 2003:38). The model is further refined by a set of 3 dates from a single 
unit, D-14, by assuming that these dates are in chronological order according to their reported depths: GaK-193, from the lower part of stratum 7; Gak-192, from the upper part of stratum 7; and GaK-195, from stratum 5 (Kigoshi and Endo 1963:116; Ponce Sanginés 1970: Table 5). Depths of other dates are reported, but none are from the same unit, leaving their stratigraphic relationships unclear (Tables 2 and 3; Wendt et al. 1962:106-7; Stuckenrath 1963:95; Ponce 1970: Table 5). Hence, there is no clear basis for depositional or accumulation models.

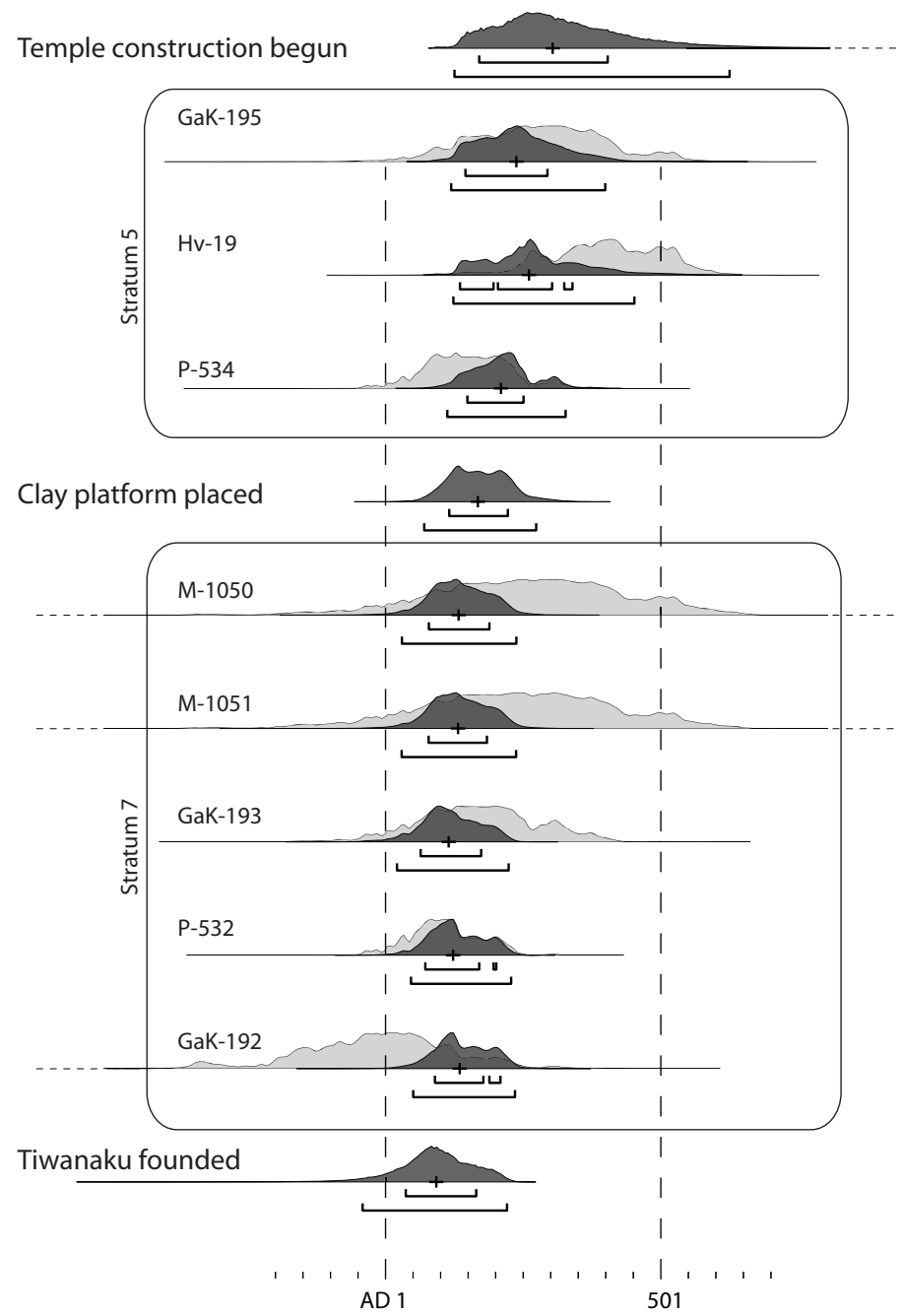

Figure 4 Calibrated and modeled dates from the sub-Kalasasaya, in light and dark gray, respectively.

The starting temporal boundary suggests Tiwanaku was founded around AD 90 (30-170). The 5 dates from stratum 7 suggest that this phase lasted from about AD 100 (50-170) to AD 160 (110220 ), and lasted less than $70 \mathrm{yr}(1 \sigma)$. The large cache of elaborate vessels in pit E-17 has a modeled date of AD 120 (70-210). 
There is a clay stratum between strata 5 and 7, modeled as a boundary event $\sim \mathrm{AD} 170$ (110-230). Above this layer are dates from stratum 5, representing an occupation of less than $130 \mathrm{yr}(1 \sigma)$, which began around AD 200 (130-240) and ended around AD 280 (170-370). Ponce Sanginés (1993:53) does not describe ceramics from this stratum, only noting that there were undecorated sherds with dense mica inclusions. The boundary between strata 4 and 5 suggests residents abandoned the area around AD $310(160-410)$, as the area was covered with construction fill for the Kalasasaya temple.

\section{DISCUSSION}

\section{Tiwanaku's Founding and Earliest Occupation}

The date of Tiwanaku's founding is estimated using the starting boundaries of models from Bennett's pit and the Kalasasaya, AD 90 (80 BC-AD 340) and AD 90 (30-170), respectively. In both cases, the earliest cultural material overlies sterile soil. These 2 data sets are independent and strongly agree, despite large error ranges. Assuming both models share a starting boundary provides a composite idea of Tiwanaku's founding date, AD 110 (50-170). This result takes into account data from both excavations, and seems to provide the most reliable estimate for the founding of Tiwan$\mathrm{aku}$, given the limitations of the data.

More recent research has confirmed that there is no clear material evidence at Tiwanaku that predates the Late Formative, despite its long history of research (Marsh, forthcoming). Currently, the only other Late Formative ${ }^{14} \mathrm{C}$ dates at Tiwanaku come from Kk'araña, a residential area north of the Kalasasaya. The earliest occupation, lying over sterile soil, dates to AD 220 (130-320) (Marsh 2012: Table 7.2).

\section{Construction Projects}

The similar clay layers found in both excavations suggest 2 roughly contemporary construction projects. In the Kalasasaya, the clay in stratum 6 was placed around AD 170 (110-230). In Bennett's pit V (1934: Figure 8), probable construction materials are located between levels 8 and 9, a boundary modeled to $\sim \mathrm{AD} 180$ (70-330). These materials may be from a single, large construction event. A second event corresponds to clay and "washed" stones (1934:385) at the same depth as Kidder's level 14, modeled to AD 290 (220-380). These construction materials may have been placed around the same time as the first stages of the construction of the Kalasasaya, $\sim A D 310(160-410)$. The temporal correlations are not clear, but it is evident that Tiwanaku witnessed a series of construction projects within the space of a few generations, as might be expected for a recently founded and rapidly growing site.

\section{Ceramic Chronology}

The ceramics from these excavations are the basis for the regional sequence proposed by Janusek (2003:54). The models presented here suggest more accurate and precise temporal ranges for each style. Kalasasaya zonally incised vessels were used only during the 2 nd century AD, and do not temporally overlap with Qeya vessels. Supporting Janusek's suggestion that Qeya vessels were used after AD 300, the model from the Kalasasaya suggests this style was used no earlier than $\sim A D 310$ $(160-410)$. This boundary may correspond to the proposed regional shift between Late Formative 1 and 2 ceramics. Kalasasaya red-rimmed bowls and small jars were common, and found throughout Late Formative levels in Bennett's and Kidder's pits (Bennett 1934:400, Table 3; Ralph 1959:55; Mohr Chávez 1987:2). Kalasasaya ceramics continue to appear in equivalent levels of Bennett's and Kidder's pits until the appearance of Tiwanaku period redwares. Tiwanaku redwares and Kalasasaya red-rimmed vessels even appear in the same level (Bennett 1934: Table 3). 
These data do not support Janusek's $(2003: 40,54)$ suggestion that there was a phase without decorated ceramics (Late Formative 1B), nor that red-rimmed vessels became less frequent over time. However, these patterns may not be representative of all contexts at Tiwanaku, let alone other nearby sites. It is clear that there was strong local variation in ceramic styles and their popularity during the Late Formative (Janusek 2003:52-4; Roddick 2009:176-7).

\section{Monolith Chronology}

The revised dates presented here have implications for the dating of monolith styles. Tiwanaku's Stela 15, the "bearded statue" (Bennett 1934:441, Figure 32), "occupies a prominent place" in the Yaya-mama style (Chávez and Mohr Chávez 1975:66). Accepting the disparate range of Ponce Sanginés' early dates, this style was originally dated to the Middle Formative, based on stylistic comparisons to the Ica "master sequence" from the Pacific coast (Rowe 1963:1, 8; see Chávez and Mohr Chávez 1975:64-9). The ${ }^{14} \mathrm{C}$ dates modeled here suggest that this monolith and others in this style in fact date to the first few centuries AD (Smith 2009:383; Marsh 2012:88-98). Stylistically similar monoliths at Khonkho Wankane have been associated with ${ }^{14} \mathrm{C}$ dates ranging from the $2 \mathrm{nd}$ to 4th centuries AD (Ohnstad 2011:139).

Research from other sites has produced a series of dates associated with Late Formative ceramic and monolith styles known from Tiwanaku. Their medians' fall after AD 1, and almost all fall after AD 100, as seen in large sets of dates from Lukurmata, Khonkho Wankane, and 3 sites on the Taraco Peninsula (Bermann 1994: Appendix III; Janusek 2003: Table 3.3; Bruno 2008: Appendix 1; Smith 2009: Figure 3.24; Marsh 2012: Figure 5.7, Table 5.7).

\section{Implications for State Formation}

A refined history of Tiwanaku has important implications for models of the state's rise. Tiwanaku was founded around the same time as other Late Formative ceremonial centers such as Khonkho Wankane, founded around AD 70 (40-120) (Marsh 2012: Table 5.7). Tiwanaku was not any larger or more important, at least initially. A relatively rapid appearance of a series of ceremonial centers throughout the southern Titicaca Basin accompanied a major shift in both material culture and social organization. This scenario does not support Ponce Sanginés' narrative, but instead seems to describe a situation much more akin to Renfrew's "early state module," similar to more recent proposals (see Stanish 2003:283-4; Janusek 2004b:114-9). The reasons that Tiwanaku became the state capital and not another ceremonial center remain unclear, but Tiwanaku's founding date is a central piece of evidence in this discussion (see Kolata 1993:84-5; Bandy 2001:293-300; Stanish 2003: 159-60; Marsh 2012:521-9).

\section{History of Tiwanaku's Earliest Occupation}

After being founded around AD 110 (50-170), Tiwanaku's population would expand rapidly within a few centuries. These people were involved in a series of construction projects, including the Sunken Temple (also called the Semi-Subterranean Temple), the Kalasasaya, and probably the first stages of the Akapana and Puma Punku (Cordero Miranda 1978:4-5, Table 2; Janusek 1994:105, 2004b:106-9; Ponce Sanginés 1995:328; Couture 2002:105-8; Vranich 2006:126, 130; Marsh 2012:463). Residential areas were built near the Kalasasaya, Kk'araña, and La Karaña (Portugal Ortiz 1992:25-9; Ponce Sanginés 1993:53-6; Janusek 2004b:100-4; Marsh 2012:123-8, Chapter 7). These construction projects are surrounded by some 81 ha of Late Formative surface ceramics, suggesting thousands of permanent residents (Lémuz Aguirre 2004:13; Marsh 2012:452). Other residential areas were first occupied at the end of the Late Formative, such as Putuni and Akapana East, 
perhaps during the transition between the Late Formative and Tiwanaku periods (Portugal Ortiz 1992:32; Janusek 1994: Chapter 7, 2004b:111; Couture 2002:110-23).

Current data suggest Tiwanaku was not a large site during most of the Late Formative, but grew precipitously thereafter (Couture 2002:105; Janusek 2004b:116; Marsh 2012:451-6). Most sectors in Tiwanaku were first occupied after AD 600, when the majority of construction took place. Rapid growth continued over the next few centuries, during which some 10,000 to 20,000 residents and visitors generated the extant $3.84 \mathrm{~km}^{2}$ area of surface artifacts (Janusek 2004b:128; Lémuz Aguirre 2004:12; Marsh 2012:456). Within a few centuries of its founding, Tiwanaku would become the focal point of a first-generation Andean state. Its ascension was a rapid process of growth, a cultural "big bang" of enduring change (Roddick 2009:374).

\section{CONCLUSION}

Further refinements to the cultural history of Tiwanaku and other nearby sites will require better exploiting the potential of Bayesian models, which have been effectively applied in other parts of the Andes (e.g. Finucane et al. 2007; Michczyński et al. 2007; Unkel 2007). I hope this study encourages researchers working in the Andes, and especially the Titicaca Basin, to take advantage of these models. Beyond the Andes, this paper may serve as an example of the potential of re-assessing dates published long ago, and how simple models can greatly refine the large standard errors of dates processed in the 1950s and 1960s.

Clarifying and improving the precision of absolute dates is fundamental to refining material culture histories. Detailed histories are necessary to address anthropological research questions, including the nature of social changes that accompanied the emergence of one of the world's primary states. Important changes took place during the Late Formative, which until recently was the region's "most obscure, complex and poorly understood period" (Lémuz Aguirre and Paz Soria 2001:105, translation by author). During this time, new, large ceremonial centers emerged, physically framing and anchoring accelerating social transformations. The use of decorated ceramic vessels was not frequent or synchronized, and styles were not always standardized. Detailed, local chronologies anchored to Bayesian models of ${ }^{14} \mathrm{C}$ dates will be necessary to trace local variability and regional generalities. Late Formative processes of change condensed at Tiwanaku during the 6th century AD, when residents, visitors, and migrants transformed into the nexus of a lasting Andean hegemony.

\section{ACKNOWLEDGMENTS}

I am indebted to John Janusek for introducing me to the archaeology of the southern Titicaca Basin. Andrew Millard, Bruce Owen, and Christopher Bronk Ramsey patiently guided me through the use of calibration curves and OxCal's syntax. Two anonymous reviewers provided valuable comments and suggestions. All errors of fact and interpretation are my own.

\section{REFERENCES}

Albarracín-Jordan JV. 2007. La Formación del Estado Prehispánico en los Andes: Origen y Desarrollo de la Sociedad Segmentaria Indígena. La Paz: Fundación Bartolomé de las Casas. $236 \mathrm{p}$.

Augustyniak S. 2004. Dating the Tiwanaku state. Chungara 36(1):19-35.

Bandy MS. 2001. Population and history in the ancient Titicaca Basin [PhD dissertation]. Berkeley: University of California.
Bennett WC. 1934. Excavations at Tiahuanaco. Anthropological Papers of the American Museum of Natural History 34:359-494.

Bermann M. 1990. Household and empire at Lukurmata, Bolivia [PhD dissertation]. Ann Arbor: University of Michigan.

Bermann M. 1994. Lukurmata: Household Archaeology in Prehispanic Bolivia. Princeton: Princeton University Press. 
Bronk Ramsey C. 2008. Deposition models for chronological records. Quaternary Science Reviews 27(1-2): $42-60$.

Bronk Ramsey C. 2009. Bayesian analysis of radiocarbon dates. Radiocarbon 51(1):337-60.

Browman DL. 1980. Tiwanaku expansion and altiplano economic patterns. Estudios Arqueológicos 5:107-20.

Bruno MC. 2008. Waranq waranqa: ethnobotanical perspectives on agricultural intensification in the Lake Titicaca Basin (Taraco Peninsula, Bolivia) [PhD dissertation]. St. Louis: Washington University.

Burkholder J. 1997. Tiwanaku and the anatomy of time: a new ceramic chronology from the Iwawe site, department of La Paz, Bolivia [PhD dissertation]. Binghamton: State University of New York.

Chávez SJ, Mohr Chávez KL. 1975. A carved stela from Taraco, Puno, Peru, and the definition of an early style of stone sculpture from the altiplano of Peru and Bolivia. Nawpa Pacha 13:45-83.

Childe GV. 1950. The urban revolution. Town and Planning Review 21:3-17.

Cordero Miranda G. 1978. Informe Preliminar acerca de las Excavaciones en Pumapunku. Internal document 33/78. La Paz: Unidad Nacional de Arqueología.

Couture NC. 2002. The construction of power: monumental space and elite residence at Tiwanaku, Bolivia [PhD dissertation]. Chicago: University of Chicago.

Finucane BC, Valdez JE, Pérez Calderon I, Vivanco Pomacanchari C, Valdez LM, O'Connell T. 2007. The end of empire: new radiocarbon dates from the Ayacucho Valley, Peru, and their implications for the collapse of the Wari state. Radiocarbon 49(2):579-92.

Hogg AG, Bronk Ramsey C, Turney C, Palmer J. 2009. Bayesian evaluation of the Southern Hemisphere radiocarbon offset during the Holocene. Radiocarbon 51(4):1165-76.

Isbell WH, Burkholder J, Albarracín-Jordan JV. 2002. Iwawi y Tiwanaku. Gaceta Arquegológica Andina 26: 139-70.

Janusek JW. 1994. State and local power in a prehispanic Andean polity: changing patterns of urban residence in Tiwanaku and Lukurmata, Bolivia $[\mathrm{PhD}$ dissertation]. Chicago: University of Chicago.

Janusek JW. 2003. Vessels, time, and society: toward a chronology of ceramic style in the Tiwanaku heartland. In: Kolata AL, editor. Urban and Rural Archaeology. Tiwanaku and Its Hinterland: Archaeological and Paleoecological Investigations of an Andean Civilization, Volume 2. Washington, DC: Smithsonian Institution Press. p 30-92.

Janusek JW. 2004a. Tiwanaku and its precursors: recent research and emerging perspectives. Journal of $\mathrm{Ar}$ chaeological Research 12(2):121-83.

Janusek JW. 2004b. Identity and Power in the Ancient Andes: Tiwanaku Cities through Time. New York: Routledge. 319 p.

Kidder AV. 1967. Digging in the Titicaca Basin. In: Rowe
JH, Menzel D, editors. Peruvian Archaeology: Selected Readings. Palo Alto: Peek. p 132-45.

Kigoshi K, Endo K. 1963. Gakushuin natural radiocarbon measurements II. Radiocarbon 5:109-17.

Kigoshi K, Tomikura Y, Endo K. 1962. Gakushuin natural radiocarbon measurements I. Radiocarbon 4:8494.

Kolata AL. 1993. The Tiwanaku: Portrait of an Andean Civilization. Cambridge: Blackwell. $317 \mathrm{p}$.

Kra R. 1986. Standardizing procedures for collecting, submitting, recording, and reporting radiocarbon samples. Radiocarbon 28(2A):765-75.

Lémuz Aguirre C. 2004. Normalización de datos de asentamiento en la cuenca sur del Lago Titicaca. Report submitted to the Unidad Nacional de Arqueología, La Paz.

Lémuz Aguirre C, Paz Soria JL. 2001. Nuevas consierdaciones acerca del periodo Formativo en Kallamarka. Textos Antropológicos 13:93-110.

Marsh EJ. 2012. The emergence of Tiwanaku: domestic practices and regional traditions at Khonkho Wankane and Kk'araña [PhD dissertation]. Santa Barbara: University of California.

Marsh EJ. Forthcoming. The founding of Tiwanaku: evidence from Kk'araña. Nawpa Pacha 32(2).

Mathews JE. 1992. Prehispanic settlement and agriculture in the middle Tiwanaku Valley, Bolivia [PhD dissertation]. Chicago: University of Chicago.

McCormac FG, Hogg AG, Blackwell PG, Buck CE, Higham TFG, Reimer PJ. 2004. SHCal04 Southern Hemisphere calibration, 0-11.0 cal kyr BP. Radiocarbon 46(3):1087-92.

Michczyński A, Eeckhout P, Pazdur A, Pawlyta J. 2007. Radiocarbon dating of the Temple of the Monkeythe next step towards a comprehensive absolute chronology of Pachacamac, Peru. Radiocarbon 49(2): 565-78.

Mohr-Chávez KL. 1987. Observations and comments on Bennett's Early Tiahuanaco material at the American Museum of Natural History [unpublished manuscript].

Oeschger H, Riesen T. 1965. Bern radiocarbon dates IV. Radiocarbon 7:1-9.

Ohnstad A. 2011. La escultura prehispánica de Khonkho Wankane, Jesús de Machaca, Bolivia. Nuevos Aportes 5:119-42.

Ponce Sanginés C. 1970. Las Culturas de Wankarani y Chiripa y su Relación con Tiwanaku. Publication 25. La Paz: Academia Nacional de Ciencias de Bolivia.

Ponce Sanginés C. 1971. La cerámica de la época I de Tiwanaku. Pumapunku 2:7-28.

Ponce Sanginés C. 1976. La cerámica de la Época I de Tiwanaku. Publication No. 18. La Paz: Instituto Nacional de Arqueología.

Ponce Sanginés C. 1981. Tiwanaku: Espacio, Tiempo y Cultura. La Paz: Editorial Los Amigos del Libro. $251 \mathrm{p}$. 
Ponce Sanginés C. 1993. La cerámica de la época I (aldeana de Tiwanaku). Pumapunku (Nueva Época) 4: $48-89$.

Ponce Sanginés C. 1995. Tiwanaku: 200 Años de Investigaciones Arqueológicas. La Paz: Producciones CIMA. 448 p.

Portugal Ortiz M. 1992. Trabajos arqueológicos de Tiwanaku (I. Parte). Textos Antropológicos 4:9-51.

Ralph EK. 1959. University of Pennsylvania radiocarbon dates III. American Journal of Science Radiocarbon Supplement 1:45-58.

Reimer PJ, Baillie MGL, Bard E, Bayliss A, Beck JW, Blackwell PG, Bronk Ramsey C, Buck CE, Burr GS, Edwards RL, Friedrich M, Grootes PM, Guilderson TP, Hajdas I, Heaton TJ, Hogg AG, Hughen KA, Kaiser KF, Kromer B, McCormac FG, Manning SW, Reimer RW, Richards DA, Southon JR, Talamo S, Turney CSM, van der Plicht J, Weyhenmeyer CE. 2009. IntCal09 and Marine09 radiocarbon age calibration curves, 0-50,000 years cal BP. Radiocarbon 51(4): $1111-50$.

Renfrew C. 1986. Introduction. In: Renfrew C, Cherry JF, editors. Peer Polity Interaction and Socio-political Change. Cambridge: Cambridge University Press. p 1-26.

Roddick AP. 2009. Communities of pottery production and consumption on the Taraco Peninsula, Bolivia, 200 BC-300 AD [PhD dissertation]. Berkeley: Uni- versity of California.

Rowe JH. 1963. Urban settlements in ancient Peru. Nawpa Pacha 1:1-27.

Smith SC. 2009. Venerable geographies: spatial dynamics, religion, and political economy in the prehistoric Lake Titicaca Basin, Bolivia [PhD dissertation]. Riverside: University of California.

Stanish C. 2003. Ancient Titicaca: The Evolution of Complex Societies in Southern Peru and Northern Bolivia. Berkeley: University of California Press.

Steadman LH. 1995. Excavations at Camata: an early ceramic chronology for the western Titicaca Basin, Peru [PhD dissertation]. Berkeley: University of California.

Stuckenrath R. 1963. University of Pennsylvania radiocarbon dates VI. Radiocarbon 5:82-103.

Stuiver M, Pearson GW. 1993. High precision bidecadal calibration of the radiocarbon time scale, AD 1950$500 \mathrm{BC}$ and 2500-6000 BC Radiocarbon 35(1):1-23.

Unkel U, Kromer B, Reindel M, Wacker L, Wagner G. 2007. A chronology of the pre-Columbian Paracas and Nasca cultures in south Peru based on AMS ${ }^{14} \mathrm{C}$ dating. Radiocarbon 49(2):551-64.

Vranich. 2006. The construction and reconstruction of ritual space at Tiwanaku, Bolivia. Journal of Field Archaeology 31(2):121-36.

Wendt I, Schneekloth H, Budde E. 1962. Hannover radiocarbon measurements I. Radiocarbon 4:100-8.

\section{APPENDIX}

\section{Model for Bennett's Pit V and Kidder's Pit A:}

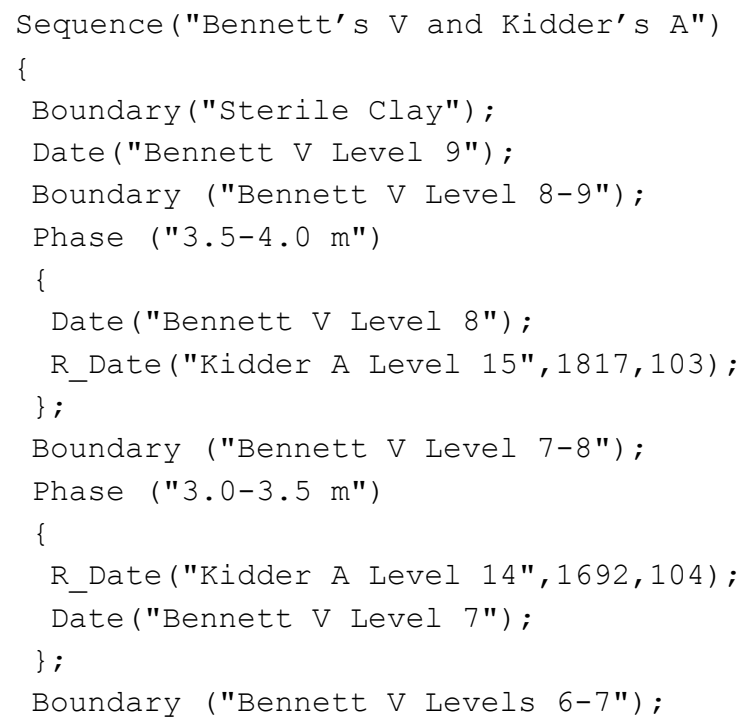




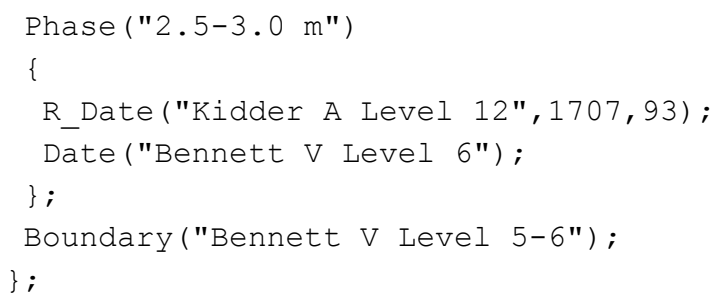

\section{Model for the Kalasasaya:}

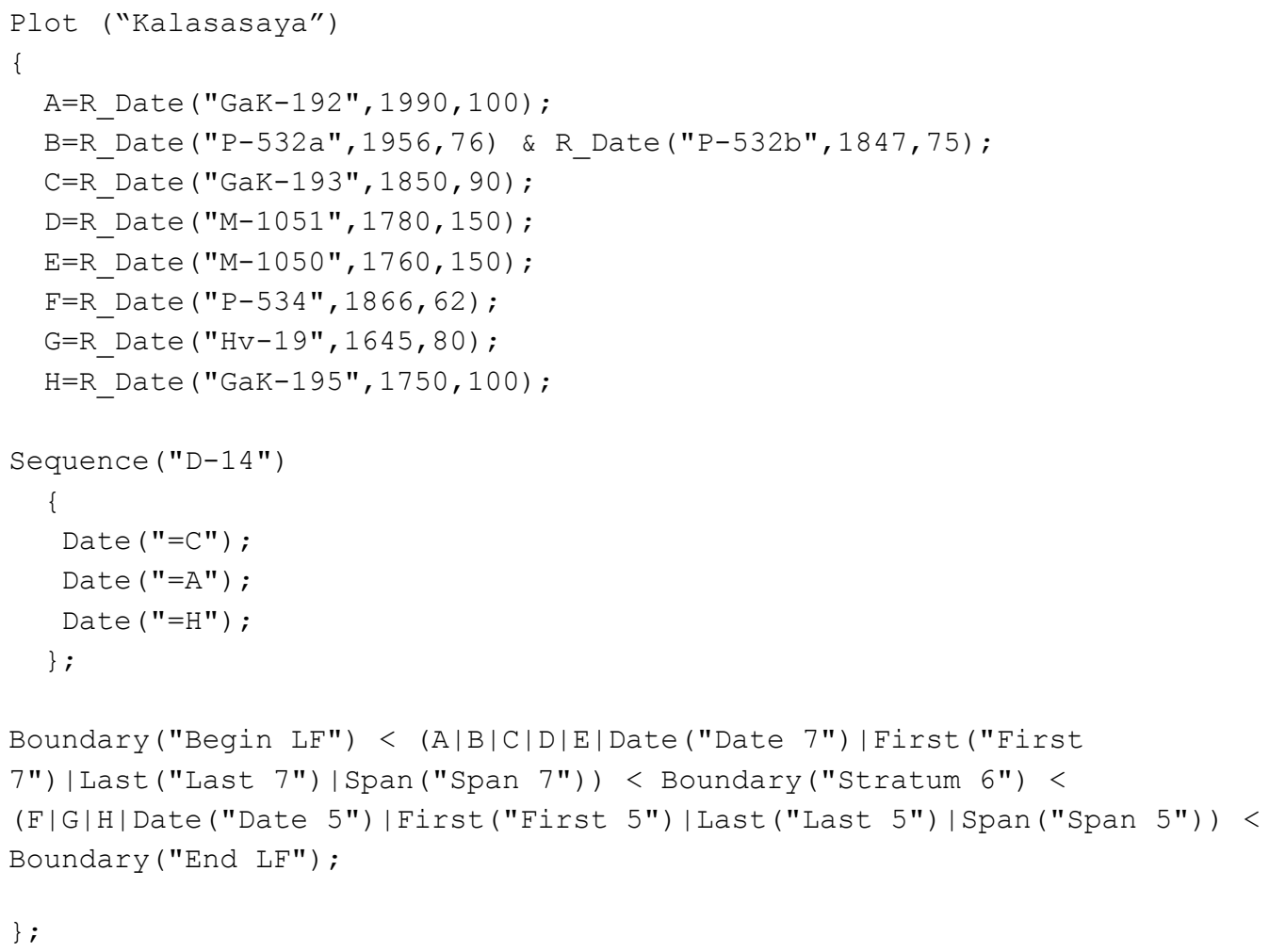

